RESEARCH ARTICLE

\title{
Phonetic and Phonological Aspects in Children with Operated Cleft Lip and Palate
}

\author{
Maria Gabriela Cavalheiro ${ }^{1 *}$, Camila de Castro Correa ${ }^{2}$, Laura Katarine Felix Andrade ${ }^{3}$ \\ and Luciana Paula Maximino ${ }^{1,3}$
}

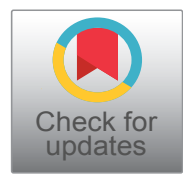

${ }^{1}$ Hospital for Rehabilitation of Craniofacial Anomalies, University of São Paulo, Bauru, SP, Brazil

${ }^{2}$ Department of Ophthalmology and Otorhinolaryngology, Botucatu Medical School - State University São Paulo, UNESP, Botucatu, SP, Brazil

${ }^{3}$ Department of Speech-Language Pathology and Audiology, Bauru School of Dentistry, University of São Paulo, Bauru, $S P$, Brazil

*Corresponding author: Maria Gabriela Cavalheiro, Hospital for Rehabilitation of Craniofacial Anomalies, University of São Paulo, Octávio Pinheiro Brisola, 9-75-17012-901, Bauru, SP, Brazil, Tel: +55-143-235-8000, E-mail: gabcavalheiro@gmail.com

\begin{abstract}
Introduction: Cleft Lip and Palate (CLP) is the most common malformation in childhood and may result in the presence of communication disorders. The consequences in speech are related to velopharyngeal dysfunction and dentofacial deformity, as the risks to phonological disorders, related to middle ear changes.

Objective: To analyze the occurrence of phonetics and phonological disorders in children aged from 3 years to 3 years and 11 months with repaired CLP.

Methods: Data from 30 children medical files were analyzed with operated CLP aged from 3 years to 3 years and 11 months, duly enrolled in a reference hospital treatment of this malformation. The data collection was made by the child's medical record information as identification, type of cleft and newer specific speech evaluation. The phonetics and phonological aspects were analyzed.

Results: There were observed compensatory articulations, phonological simplifications (phonological disorders) and side lisp (phonetics disorder).

Conclusion: Besides the Compensatory articulations, phonological simplifications and articulatory distortions were also present in children with operated CLP, accentuating the impaired speech intelligibility.
\end{abstract}

\section{Keywords}

Speech, Language and hearing sciences, Cleft lip, Cleft palate

\section{Introduction}

The Cleft Lip and Palate (CLP) occur during the first quarter of intrauterine development, and has multifactorial origin [1]. This is one of the most common malformations of childhood [2], affecting 1 in every 650 live births in Brazil [3]. CLP may result in the presence of communication disorders, covering different aspects such as articulation, resonance, hearing, speech and/or language.

The CLP consequences of speech are mainly justified by the commitment of anatomical structures involved in speech production, related to velopharyngeal dysfunction and Dentofacial deformity [4-7].

The speech alterations resulting from velopharyngeal dysfunction affect speech intelligibility of individuals may persist even after surgical correction of the palate [8], the most common hypernasality, the nasal air emission and compensatory articulations.

The risks for language change, the changes are given in the middle ear, such as frequent episodes of otitis media with sensory deprivation, which can lead to phonological errors [9]. As for the different aspects of language in the early stages of language development, problems of resonance and articulation can cause phonetic and phonological changes and thus significantly interfere with the quality of speech. It notes that the

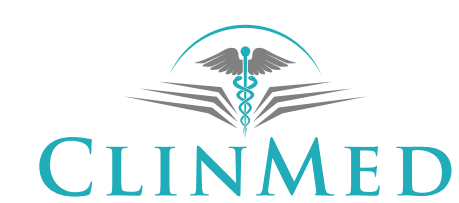

INTERNATIONAL LIBRARY
Citation: Cavalheiro MG, Correa CC, Andrade LKF, Maximino LP (2017) Phonetic and Phonological Aspects in Children with Operated Cleft Lip and Palate. Int Arch Commun Disord 1:002. Received: June 29, 2017; Accepted: September 26, 2017; Published: September 28, 2017

Copyright: (C) 2017 Cavalheiro MG, et al. This is an open-access article distributed under the terms of the Creative Commons Attribution License, which permits unrestricted use, distribution, and reproduction in any medium, provided the original author and source are credited. 
phonological simplifications not expected for chronological age, also interfere with speech intelligibility [10].

The literature does not provide conclusive evidence on the development of phonological system in children with CLP, which may occur in a similar way to the other children, but can also present the phonological disorder. Given conflicting results, it is necessary to investigate the presence not only of speech disorders, such as aspects of the language that interfere with speech intelligibility of these children.

\section{Objective}

Analyze the occurrence of phonetics and phonological disorders in children aged from 3 years to 3 years and 11 months with repaired CLP.

Table 1: Classification of evaluation results by speech and language analysis.

\begin{tabular}{|l|l|}
\hline Speech evaluation & Example \\
\hline $\begin{array}{l}\text { Compensatory } \\
\text { articulations }\end{array}$ & $\begin{array}{l}\text { Glottal stop, Pharyngeal fricative, } \\
\text { Velar fricative, Pharyngeal stop, } \\
\text { Velar stop e mid-dorsum palatal } \\
\text { stop }\end{array}$ \\
\hline $\begin{array}{l}\text { Phonological } \\
\text { simplifications }\end{array}$ & $\begin{array}{l}\text { Substitution process and Structure } \\
\text { syllabic }\end{array}$ \\
\hline Articulatory distortions & $\begin{array}{l}\text { Anterior lisp, Side lisp and Side } \\
\text { distortions }\end{array}$ \\
\hline
\end{tabular}

Table 2: Sample distribution by type of Cleft Lip and Palate, considering the number of subjects, percentage and mean age in months.

\begin{tabular}{|l|l|l|l|}
\hline Cleft type & n & \% & Age \\
\hline Cleft palate & 12 & 40 & 41.9 \\
\hline Cleft lip and palate & 18 & 60 & 39.9 \\
\hline
\end{tabular}

$\mathrm{n}$ : Number of subjects; \%: Percentage of subjects by cleft type.

\section{Methods}

\section{Ethic aspects}

The study was approved by the Human Research Ethical Commission of the institution concerned, under the protocol number 1.155.108.

\section{Casuistry}

Data from 30 children medical files were analyzed with repaired CLP aged from 3 years to 3 years and 11 months, duly enrolled in a reference hospital treatment of this malformation.

As exclusion criteria, children with diagnoses of genetic syndromes and otitis history were not part of this study.

\section{Procedures}

The data collection was made by examining the child's medical record information for identification, type of cleft $[11,12]$ and newer specific speech evaluation.

The item found in the specific clinical assessment was the phonetic frame, represented by a given speech sample based on directed speech and images. Thus, the possible findings of this speech and language evaluation were classified as detailed in Table 1.

\section{Data analysis}

Data were submitted to descriptive analysis quantitatively and presented in tables and figures.

\section{Results}

The majority of the sample consisted of children with cleft lip and palate $(60 \%)$. The characterization of the sample showed 16 male children and 14 female, with overall average age of 40 months group (Table 2 ).

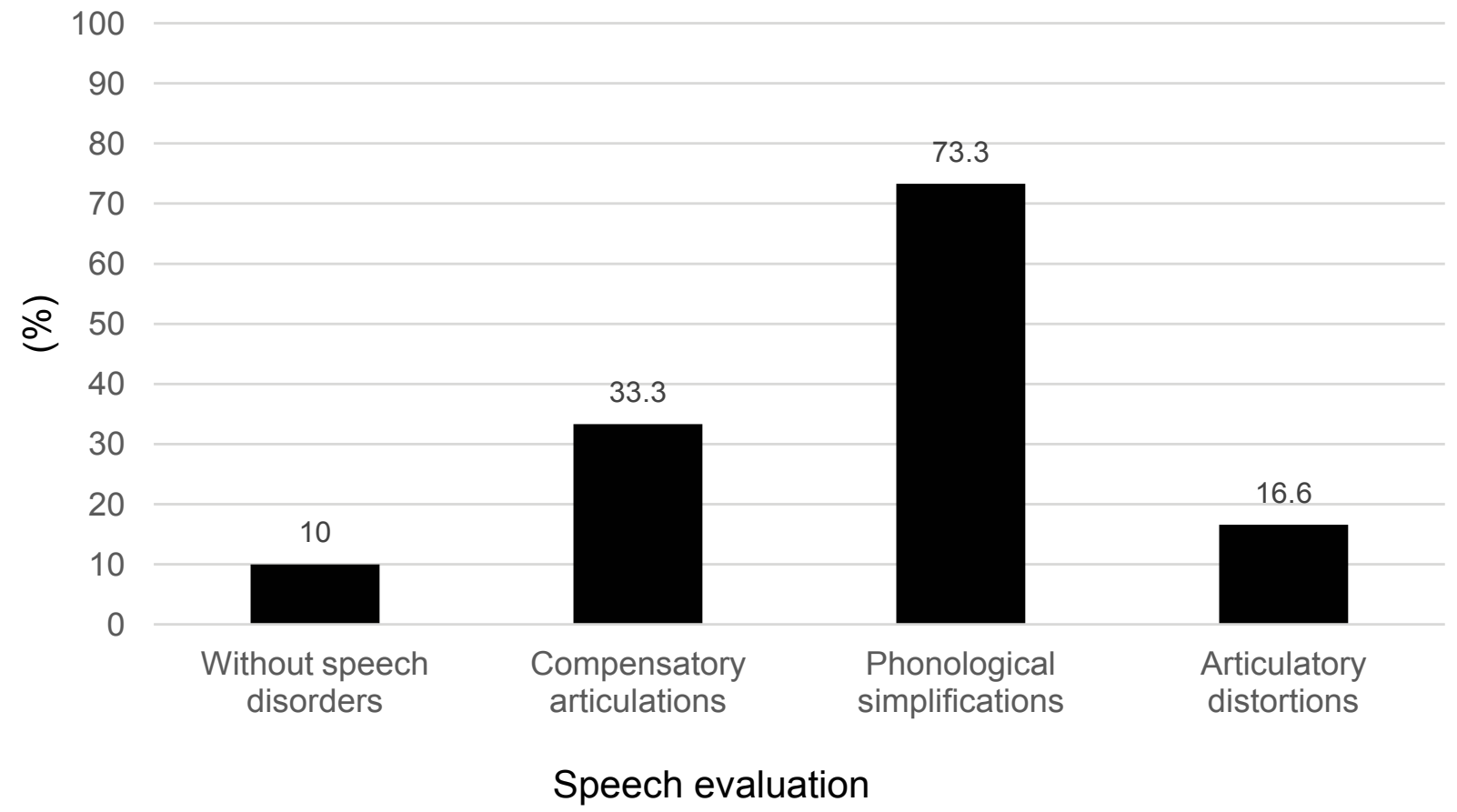

Figure 1: Speech evaluation in percentage. 
As for the quality of speech, it was observed that 10 children had compensatory articulations, 22 had phonological simplifications not expected for age and 5 showed articulatory distortions, as shown in Figure 1. It is noteworthy that the same child might have different speech disorders and 3 children no showed speech disorders.

Compensatory articulations present in the sample were Coup glottis, Pharyngeal fricative and velar fricative. Phonological simplifications not appropriate to chronological age were mostly type replacement, and only 2 children presented syllable simplification (structural). Regarding articulatory distortions occurred more frequently the Side Lisp.

\section{Discussion}

The thematic basis of this study stems from the concern to analyze a particular function, in this case, the speech, in a comprehensive manner, considering different characteristics that make it up, so that in this way, the design of the therapeutic process is based on the process of communication.

The occurrence of cleft lip and palate was predominant, as the literature demonstrates $[13,14]$. It is still possible to attribute the speech alterations to the type of fissure most found in the sample, because the language are directly related to more extensive clefts $[15,16]$.

There was a predominance of occurrence of phonological simplifications not expected for age of the children. While it is expected the acquisition of similar phonological system between children with and without cleft; no language delay was reported in children with cleft [16-18]. Then there is the presence of compensatory articulations in $16.6 \%$ of the sample value, below the Bzoch (1997) and Seguimotto (2002) findings $[19,20]$, who reported the persistence of compensatory articulations in approximately $30 \%$ of children with CLP after surgery, inserted into multidisciplinary care. Lower occurrence of articulatory distortions. The absence of speech disorders in part of this population after surgery is scheduled for literature [19-21].

Knowing the complexity of the communication process also should be investigated in future research. The occurrence of the change of speech due to possible changes in the auditory system, should consider the possibility of changes in the middle ear function in these children.

\section{Conclusion}

Besides the Compensatory articulations, phonological simplifications and articulatory distortions were also present in children with operated CLP, which accentuated the impaired speech intelligibility. Thus, during the evaluation of speech in this population, it is necessary to clinically look not only the changed anatomical and physiological aspects, but also velopharyngeal function and phonological development.

\section{Financing}

None.

\section{Conflict of Interests}

None.

\section{References}

1. Aquino SN, Paranaíba LM, Martelli DR, Swerts MS, Barros LM, et al. (2011) Study of patients with cleft lip and palate with consanguineous parents. Braz $\mathrm{J}$ Otorhinolaryngol 77: 19-23.

2. Canfield MA, Honein MA, Yuskiv N, Xing J, Mai CT, et al. (2006) National estimates and race/ethnic-specific variation of selected birth defects in the United States, 1999-2001. Birth Defects Res A Clin Mol Teratol 76: 747-756.

3. Derijcke A, Eerens A, Carels C (1996) The incidence of oral clefts: A review. Br J Oral Maxillofac Surg 34: 488-494.

4. Hardin Jones MA, Chapman KL, Wright J, Halter KA, Schulte J, et al. (2002) The impact of early palatal obturation on consonant development in babies with unrepaired cleft palate. Cleft Palate Craniofac J 39: 157-163.

5. Chapman KL (2011) The relationship between early reading skills and speech and language performance in young children with cleft lip and palate. Cleft Palate Craniofac J 48: 301-311.

6. Genaro KF, Yamashita RP, Trindade IEK (2004) Avaliação clínica e instrumental na fissura labiopalatina. In: Ferreira LP, Befi-Lopes DM, Limonge SCO (Org.). Tratado de Fonoaudiologia, São Paulo, Roca, 456-493.

7. Pegoraro Krook MI, Dutka Souza JC, Magalhães LCT, Feniman MR (2004) Intervenção fonoaudiológica na fissura palatina. In: Ferreira LP, Befi-Lopes DM, Limonge SCO (Org.). Tratado de Fonoaudiologia, São Paulo, Roca.

8. Dutka JCR, Pegoraro Krook MI (2014) Avaliação e tratamento das disfunções velofaríngeas. In: Marchesan I, Justino $\mathrm{H}$, Tomé $\mathrm{M}$ 3ed (Org). Tratado das Especialidades em fonoaudiologia. São Paulo, Guanabara koogan 363-368.

9. Amaral MIR, Martins JE, Santos MFC (2010) Estudo da audição em crianças com fissura labiopalatina não-sindrômica. Braz J Otorhinolaryngol 76.

10. Wertzner HF (2002) O distúrbio fonológico em crianças falantes do português: Descrição e medidas de severidade. Faculdade de Medicina da Universidade de São Paulo, São Paulo, Brazil, 228.

11. Spina V, Psillakis JM, Lapa FS, Ferreira MC (1972) Classificação das fissuras lábio-palatinas:sugestão de modificação. Rev Hosp Clin Fac Med S Paulo 27: 5-6.

12. Silva Filho OG, Ferrari Júnior FM, Rocha DL, Souza Freitas JA (1992) Classificação das fissuras lábio-palatais: Breve histórico, considerações clínicas e sugestão de modificação. Rev Bras Cir 82: 59-65.

13. Cymrot M, Sales FCD, Teixeira FAA, Teixeira Junior FAA, Teixeira GSB, et al. (2010) Prevalência dos tipos de fissura em pacientes com fissuras labiopalatinas atendidos em um Hospital Pediátrico do Nordeste brasileiro. Rev Bras Cir Plást 25: 648-651.

14. Alonso N, Tanikawa DYS, De Lima J, Jonas E, Rocha DL, et al. (2009) Fissuras labiopalatinas: Protocolo de atendi- 
mento multidisciplinar e seguimento longitudinal em 91 pacientes consecutivos. Rev Bras Cir Plást 24: 176-181.

15. Fox D, Lynch J, Brookshire B (1978) Selected developmental factors of cleft palate children between two and thirty-three months of age. Cleft Palate J 15: 239-245.

16. Lynch JI, Fox DR, Brookshire BL (1983) Phonological proficiency of two cleft palate toddlers with school-age follow-up. J Speech Hear Disord 48: 274-285.

17. Scherer NJ, D’Antonio LL (1995) Parent questionnaire for screening early language development in children with cleft palate. Cleft Palate Craniofac J 32: 7-13.

18. Moraes TFD, Maximino LP, Feniman MR (2011) A habilidade de atenção auditiva sustentada em crianças com fissura labiopalatina e transtorno fonológico. Rev Soc Bras Fonoaudiol 16: 436-440.

19. Bzoch KR (1997) Clinical assessment, evaluation, and management of 11 categorical aspects of cleft palate speech disorders. In: Bzoch KR, Communicative Disorders Related to Cleft Lip and Palate. Pro-Ed, Austin, USA.

20. Suguimoto MLFCP (2002) Análise da fala de indivíduos operados de palate, entre 12 e 24 meses de idade: Estudo retrospective. Hospital for Rehabilitation of Craniofacial Anomalies, University of São Paulo, Bauru, SP, Brazil.

21. Williams WN, Seagle MB, Nackashi AJ, Marks R, Boggs SR, et al. (1998) A methodology report of a randomized prospective clinical trial to assess velopharyngeal function for speech following palatal surgery. Control Clin Trials 19: 297-312. 